\title{
RAB12 wt Allele
}

National Cancer Institute

\section{Source}

National Cancer Institute. RAB12 wt Allele. NCI Thesaurus. Code C142755.

Human RAB12 wild-type allele is located in the vicinity of $18 p 11.22$ and is approximately

$30 \mathrm{~kb}$ in length. This allele, which encodes Ras-related protein Rab-12, plays a role in vesicle transport. 